\title{
Crk-Like Protein
}

National Cancer Institute

\section{Source}

National Cancer Institute. Crk-Like Protein. NCI Thesaurus. Code C17700.

Crk-like protein (303 aa, $34 \mathrm{kDa}$ ) is encoded by the human CRKL gene. This protein is involved in both protein phosphorylation and signal transduction. 